\title{
Productive and Reproductive Performance of Ewes at 60 and 90 Days Postpartum Treated by Different Weaning System
}

\author{
N. da S. Heimbach, C. C. B. F. Ítavo, L. C. V. Ítavo, A. M. Dias, G. dos S. Difante, F. de A. Borges, A. L. \\ C. Gurgel*, K. L. da S. Monteiro, C. O. de O. Frangiotti, T. F. F. de S. Arco, M. C. M. da Costa, \& M. V. \\ G. Niwa \\ Faculty of Veterinary Medicine and Animal Science, Federal University of Mato Grosso do Sul \\ Av. Senador Filinto Muller, 2443, CEP: 79074-460, Campo Grande, MS, Brazil \\ *Corresponding author: antonioleandro09@gmail.com \\ (Received 17-03-2020; Revised 07-05-2020; Accepted 11-05-2020)
}

\begin{abstract}
Based on the assumption that the time required by the lamb to reach a certain weight at slaughter (slaughter weight) is partially dependent on the amount of milk ingested during suckling, and on the dietary management of the sheep and lamb. Our study proposes to examine the effects of the weaning system on the productive and reproductive performance of ewes supplemented with creep-feeding during grazing on Marandu pastures with their lambs and weaned at two different ages (60 and 90 days). Ewes were divided into two treatment groups (weaning ages) according to birth type (single or twin), in two consecutive years. The experimental period was the time from lambing to weaning. Data were evaluated by analysis of variance and means were compared by Tukey's test at the 0.05 significance level. There was no effect of year of observation on the parameters measured. Ewes did not show any differences in age and weight at lambing, weight at weaning, weight change, or time return to estrus. The average weight loss was $6 \mathrm{~kg}$ and the average time to return to estrus was 49 days. The highest averages for weaning weight $(23.25 \mathrm{~kg})$ and total weight gain $(19.37 \mathrm{~kg})$ of lambs, and lamb weight-to-ewe weight ratio $(51.84 \%)$ were observed in weaning at 90 days of age. Body condition score and worm egg count per gram of feces of ewes were not affected by the treatments. The reproductive and productive performance of sheep on tropical pastures is not affected by the weaning system. It is recommended to conduct weaning at 90 days to obtain a better performance of lambs.
\end{abstract}

Keywords: ewes; grazing; reproduction; suckling lambs; Brachiaria spp.

\section{INTRODUCTION}

Ewes tend to be seasonal polyestrous animals, expressing their sexual activity in short photoperiods; i.e., at the times of low luminosity. Light rays are captured by the photoreceptors in their eyes and then transmitted by the central nervous system to the hypothalamus and later to the pineal gland where are converted from nervous to hormonal signal, which has the characteristic of a melatonin-secretion circadian rhythm (Souza et al., 2016). By contrast, when reared in tropical climates, ewes will typically cycle all year long, thus classified as continuous polyestrous. This condition is a common occurrence in the state of Mato Grosso do Sul, Brazil.

Ewe performance is an extremely important factor in sheep farming, as it affects both lamb production and growth. During their first weeks of life, lambs are generally dependent on maternal milk, and in case of milk production decreased their performance, development, and future production will be compromised, culminating in economic and productive losses. After lambing, the nutritional requirements of ewes increase. When these requirements cannot be met, their body reserves are mobilized and reduced, which leads to a decline in the production of milk and reproductive hormones that eventually possibly causing anestrus (Sasa et al., 2011).

Anestrus is the term given to a lack of estrus behavior and ovulation. Postpartum anestrus is the period between lambing and the onset of the first estrus when uterine involution takes place and ovarian activity is resumed. The length of this period depends on nutritional and physiological factors pertaining to the animal (Assis et al., 2011), and the reproductive performance of ewes is related to how late is postpartum-ovarian activity resumed (Eloy et al., 2011). The nursing period directly contributes to prolonging anestrus, as it reduces luteinizing hormone pulses (Urbano et al., 2017).

By supplementing ewes in early lactation, it is possible to anticipate their return to reproductive activity and reduce the length of postpartum anestrus (Leal et al., 2010). Un-supplemented grazing ewes typically resume their reproductive activities only at the beginning of the rainy season, due to the higher herbage availability and nutrient uptake. Pre- and postpartum ewes are highly susceptible to worm infections; for this reason, the number of eggs eliminated in their feces increases, 
contaminating the rearing environment (Chaparro et al., 2016; Zvinorovaa et al., 2016). The use of supplementation for ewes and lambs also contributes, in this regard, to the elevation of their resistances that eventually reduces the occurrence of worm infection (Melo et al., 2017; Gurgel et al., 2020). Moreover, supplementing suckling lambs with creep feeding reduces their suckling intensity and the energy requirements from milk, which benefits the ewe in terms of body condition score, ovulation, conception, and lambing rates, as well as the occurrence of estrus (Valente et al., 2012; Valente et al., 2014; Lopes et al., 2014; Lopes et al., 2017).

For the lamb to reach an ideal weight for slaughtering with high levels of finishing quality, it is necessary that the animal goes through the breeding steps as quickly as possible. Thus, the animal must be able to consume solid food in sufficient quantity to meet nutritional requirements and use volatile fatty acids as an energy source (Urbano et al., 2017). In addition, lamb supplementation combined with a correct weaning period can be an alternative to increase weight development and, consequently, the production of lambs for slaughtering.

Thus, this research was carried out to evaluate the performance and return to estrus interval of supplemented ewes grazing on Brachiaria brizantha. Our hypothesis was the system of weaning at different days cannot modify the productive or reproductive performances of ewes but can alter the productive performance of lambs.

\section{MATERIALS AND METHODS}

\section{Experiment Location and Duration}

The experiment was conducted in the sheep sector of farm-school $\left(20^{\circ} 26^{\prime} 34.31^{\prime \prime} \mathrm{S} 54^{\circ} 50^{\prime} 27.86^{\prime \prime} \mathrm{W}\right.$; 530, 7m altitude) of Faculty of Veterinary Medicine and Animal Science (FAMEZ) at UFMS, located in Terenos - MS, Brazil. The animals were evaluated from birth to weaning (60 or 90 days of age). This period began on April 26 and lasted until August 20, 2015, while the second period was from March 15 to June 30, 2016. These periods comprised the end of the period of greatest water availability and the beginning of the water shortage seasonin the Brazilian Cerrado biome (autumn/winter).

\section{Animals and Sources of Variation}

Sheep were used without a defined racial pattern with an average age of 45 months, with average weight at lambing approximately $51.8 \mathrm{~kg}$. Ewes and their respective lambs were kept in Marandu pastures (Brachiaria brizantha), the 3.4 ha area was divided into six paddocks. Three paddocks per treatment were used (lamb weaning age: 60 or 90 days), in a grazing method under continuous stocking with variable stocking rate. Ewe lambs were used whenever necessary to adjust herbage allowance. Twenty-eight ewes were used in the first year (2015) (14 per treatment) and 32 ewes were used in the second year (2016) (16 per treatment).
Before the start of the experimental period, the ewes were dewormed with $1 \mathrm{~mL}$ of avermectin-based dewormer subcutaneously. Also, every 30 days weighings and feces were collected to determine the egg count per fecal gram (EPG), determination of the degree of anemia (Famacha method), and evaluation of body condition score (BCS). The last variable was assessed by palpation in the lumbar region between the 12th and 13 th rib and assigning scores from 1 to 5 ( $1=$ lean, $5=$ fat, and 3 being considered ideal) (Pompeu et al., 2009).

\section{Diets}

The ewes received a concentrated supplement of 350 grams per day. Supplementation was calculated to meet $30 \%$ of the requirements for lactating ewes with an average weight of $50 \mathrm{~kg}$ (BW) and daily consumption of $1.26 \mathrm{~kg}$ of dry matter (DM), according to the recommendations of the NRC (2007) (Table 1). The animals had access ad libitum to water and mineral salt, regardless of the treatment.

The forage mass was estimated by cutting the forage contained within four areas of $0.5 \mathrm{~m}^{2}$ distributed randomly by paddock. The samples were packed in paper bags, weighed, and dried in an oven with forced air ventilation at $55^{\circ} \mathrm{C}$ until constant weight when they were weighed again to estimate the forage mass (Fernandes et al., 2020). To evaluate the morphological components, subsamples were taken from the samples collected to determine the forage mass. These were separated into leaves (leaf blade), stem, and dead material (Fernandes et al., 2020).

\section{Laboratory Analysis}

The forage and concentrate samples were ground in a $1 \mathrm{~mm}$ knife mill and subsequently analyzed to estimate the concentrations of DM, organic matter (MO $=100-$ ash), crude protein (PB), and ether extract (EE) according to the methods AOAC (2000) 930.15, 932.05, 976.05, and 920.39, respectively. The neutral detergent fiber (NDF) was determined according to procedures described by Mertens (2002) using heat-stable amylase without sodium sulfite and expressed even as residual ash.

\section{Performance and Return to Estrus}

The variations in the weights of ewes were determined by the difference between birth and weaning weights. Return to estrus was monitored using one vasectomized contemporary marker ram per each paddock at 15 days postpartum, which would be left with the females during the entire time. The sternum region of the marker rams was painted with powder paint and vegetable oil to mark the lumbar region of the females showing estrus. Marked females were identified daily.

\section{Parasite Control}

The sheep were treated for parasitic infection every 30 days, the sample of each animal was taken directly 
from the rectal ampoule to determine the number of eggs per gram of feces (Melo et al., 2017). These analyzes were performed at the FAMEZ Parasitology Laboratory, and the animals were dewormed whenever they had an EPG count equal to or greater than 1000, with active ingredients based on nitroxinil.

\section{Statistical Analysis}

The experiment was conducted as a completely randomized design with a $2 \times 2$ factorial arrangement. The first factor was the type of birth consisted of 2 levels, i.e., single and twin. The second factor was the age of weaning lamb consisted of 2 levels, i.e., 60 and 90 days. The analysis was conducted according to the following statistical model: $Y=m+W A+B T+W A * B T+Y e$ $+\mathrm{e}$, where $\mathrm{Y}$ was the observed value for the evaluated variable; $\mathrm{m}$ is the overall constant; WA was the effect of the lamb weaning age (60, 90 days); BT was the effect of the birth type $(1,2)$; WA*BT was the weaning age $\times$ birth type interaction effect; Ye was the effect of the year (1, $2)$; and e was the random effect associated with each observation. Data were evaluated by analysis of variance

Table 1. Chemical composition of the supplement given to the experimental ewes

\begin{tabular}{lc}
\hline \multicolumn{1}{c}{ Item } & Amount \\
\hline Dry matter $(\mathrm{g} / \mathrm{kg})$ & 908.3 \\
Mineral matter $(\mathrm{g} / \mathrm{kg})$ & 51.6 \\
Organic matter $(\mathrm{g} / \mathrm{kg})$ & 948.4 \\
Crude protein $(\mathrm{g} / \mathrm{kg})$ & 200.3 \\
Ether extract $(\mathrm{g} / \mathrm{kg})$ & 30.0 \\
Neutral detergent fiber $(\mathrm{g} / \mathrm{kg})$ & 21.53 \\
Acid detergent fiber $(\mathrm{g} / \mathrm{kg})$ & 5.52 \\
Total digestible nutrients $(\mathrm{g} / \mathrm{kg})$ & 774.6 \\
Metabolizable energy $(\mathrm{Mcal} / \mathrm{kg} \mathrm{DM})$ & 2.8 \\
\hline
\end{tabular}

Note: Ingredients/kg= $761.1 \mathrm{~g}$ corn; $198.9 \mathrm{~g}$ soybean meal; $40 \mathrm{~g}$ calcium carbonate. and means were compared by Tukey's test at the 0.05 significance level.

\section{RESULTS}

There was no effect of year for all variables of the chemical composition of pastures (Table 2). The average herbage allowance was $2082.4 \mathrm{~g}$ of DM/ha. This amount consisted of $24.8 \%$ leaves, $39.9 \%$ stems, and $35.5 \%$ senescent material. No significant differences were detected in the chemical analyses of the herbage between the treatments. Therefore, the results were combined.

\section{Ewes and Lambs Performance and Return to Estrus}

There was no effect of year of observation on all variables of ewe and lamb performances. There was no effect of the sources of variation tested on mean age at birth (45 months), birth weight $(51.8 \mathrm{~kg})$, or weaning weight $(45.7 \mathrm{~kg})$. The weight change observed in the ewes from lambing to weaning was a 6-kg loss. Although the ewes did not show significant differences in terms of performance, single-born lambs were heavier at birth than their twinborn counterparts. Lamb weight at weaning, total weight gain, and lamb weight-to-ewe weight ratio varied according to age at weaning, with the highest values observed in the group that weaned their lambs at 90 days of age (respective means: 23.25 $\mathrm{kg}, 19.37 \mathrm{~kg}$, and $51.84 \%$ ). Return to estrus was not significantly influenced by the birth type, age at weaning, or the interaction between these two factors. The average return-to-estrus interval postpartum was 49.5 days (Table 3).

\section{Body Condition Score and Parasite Control of the Ewes}

The initial and final BCS of the ewes were not affected by the weaning age and birth type (Table 4). The highest percentage of ewes that weaned their lambs at

Table 2. Chemical composition of stem and leaf of Brachiaria brizantha cv. Marandu by month in each treatment (lamb weaning ages)

\begin{tabular}{|c|c|c|c|c|c|}
\hline \multirow{3}{*}{ Compounds } & \multicolumn{5}{|c|}{ Weaning age } \\
\hline & \multicolumn{2}{|c|}{60 days } & \multicolumn{3}{|c|}{90 days } \\
\hline & Month 1 & Month 2 & Month 1 & Month 2 & Month 3 \\
\hline \multicolumn{6}{|l|}{ Stem } \\
\hline $\mathrm{DM}(\mathrm{g} / \mathrm{kg})$ & 350.0 & 268.1 & 339.4 & 307.15 & 354.6 \\
\hline $\mathrm{OM}$ (g/kg DM) & 935.6 & 950.0 & 920.2 & 921.25 & 921.9 \\
\hline $\mathrm{CP}$ (g/kg DM) & 56.0 & 46.0 & 39.2 & 57.15 & 62.5 \\
\hline EE (g/kg DM) & 9.0 & 5.4 & 8.8 & 6.35 & 5.1 \\
\hline NDF (g/kg DM) & 675.5 & 579.95 & 682.0 & 643.2 & 674.9 \\
\hline $\mathrm{ADF}(\mathrm{g} / \mathrm{kg} \mathrm{DM})$ & 634.2 & 569.2 & 590.5 & 565.2 & 550.8 \\
\hline \multicolumn{6}{|l|}{ Leaf } \\
\hline $\mathrm{DM}(\mathrm{g} / \mathrm{kg})$ & 347.2 & 373.9 & 347.1 & 358.6 & 357.9 \\
\hline $\mathrm{OM}$ (g/kg DM) & 913.9 & 918.5 & 921.5 & 905.7 & 919.6 \\
\hline CP (g/kg DM) & 108.1 & 101.2 & 105.8 & 116.1 & 495.8 \\
\hline $\mathrm{EE}(\mathrm{g} / \mathrm{kg} \mathrm{DM})$ & 16.1 & 18.1 & 16.0 & 16.3 & 10.9 \\
\hline NDF (g/kg DM) & 604.9 & 515.5 & 545.8 & 509.0 & 498.6 \\
\hline $\mathrm{ADF}(\mathrm{g} / \mathrm{kg} \mathrm{DM})$ & 393.0 & 373.9 & 388.9 & 340.5 & 358.7 \\
\hline
\end{tabular}

Note: $\mathrm{DM}=$ dry matter; $\mathrm{OM}=$ organic matter; $\mathrm{CP}=$ crude protein; $\mathrm{EE}=$ ether extract; $\mathrm{NDF}=$ neutral detergent fiber; $\mathrm{ADF}=$ acid detergent fiber. 
Table 3. Productive and reproductive performance of ewes supplemented while grazing on Marandu pastures by weaning age and birth type

\begin{tabular}{|c|c|c|c|c|c|c|c|c|c|c|}
\hline \multirow{3}{*}{ Variables } & \multicolumn{6}{|c|}{ Weaning age } & \multirow{3}{*}{ SEM } & \multirow{3}{*}{ P1 } & \multirow{3}{*}{ P2 } & \multirow{3}{*}{ P3 } \\
\hline & \multicolumn{3}{|c|}{60 days } & \multicolumn{3}{|c|}{90 days } & & & & \\
\hline & $\begin{array}{l}\text { Single } \\
\text { birth }\end{array}$ & $\begin{array}{l}\text { Twin } \\
\text { birth }\end{array}$ & Mean & $\begin{array}{l}\text { Single } \\
\text { birth }\end{array}$ & $\begin{array}{l}\text { Twin } \\
\text { birth }\end{array}$ & Mean & & & & \\
\hline \multicolumn{11}{|l|}{ Ewes } \\
\hline Age (months) & 46 & 49 & 48 & 45 & 60 & 53 & 2.964 & 0.3848 & 0.1420 & 0.2912 \\
\hline Weight at lambing (kg) & 49.93 & 53.30 & 51.61 & 51.09 & 52.5 & 51.82 & 1.290 & 0.9388 & 0.3475 & 0.7069 \\
\hline Weight at weaning $(\mathrm{kg})$ & 45.44 & 45.05 & 45.24 & 45.45 & 47.01 & 46.23 & 1.056 & 0.6401 & 0.7805 & 0.6431 \\
\hline Weight change (kg) & -4.49 & -8.25 & -6.37 & -5.64 & -5.53 & -5.58 & 0.948 & 0.6693 & 0.3248 & 0.2966 \\
\hline Return to estrus (days) & 35.30 & 60.00 & 47.65 & 51.90 & 50.71 & 51.31 & 4.955 & 0.6965 & 0.2156 & 0.1740 \\
\hline \multicolumn{11}{|l|}{ Lambs } \\
\hline Birth weight (kg) & $4.67^{\mathrm{a}}$ & $3.12^{\mathrm{b}}$ & 3.89 & $4.15^{\mathrm{a}}$ & $3.61^{\mathrm{b}}$ & 3.88 & 0.167 & 0.9567 & 0.0003 & 0.0588 \\
\hline Weaning weight $(\mathrm{kg})$ & 17.15 & 15.23 & $16.19^{b}$ & 22.91 & 23.59 & $23.25^{\mathrm{a}}$ & 1.067 & 0.0002 & 0.7188 & 0.4521 \\
\hline Total weight gain $(\mathrm{kg})$ & 12.48 & 12.12 & $12.30^{\mathrm{b}}$ & 18.76 & 19.98 & $19.37^{a}$ & 1.042 & 0.0002 & 0.7989 & 0.6349 \\
\hline Daily gain (g/day) & 208.00 & 202.00 & $205.00^{\mathrm{b}}$ & 208.44 & 222.00 & $215.22^{\mathrm{a}}$ & 1.042 & 0.0002 & 0.7989 & 0.6349 \\
\hline $\begin{array}{l}\text { Lamb weight-to-dam } \\
\text { weight ratio }\end{array}$ & 37.81 & 33.71 & $35.76^{\mathrm{b}}$ & 50.98 & 52.69 & $51.84^{\mathrm{a}}$ & 2.590 & 0.0007 & 0.7819 & 0.5008 \\
\hline
\end{tabular}

Note: P1= weaning age; P2 = birth type; P3 = interaction between weaning age and birth type. Means in the same row with different superscripts differ significantly $(\mathrm{p}<0.05)$.

Table 4. Body condition score (BCS) and egg count per gram of feces (EPG) of the ewes supplemented while grazing on Marandu pastures by weaning age and birth type

\begin{tabular}{|c|c|c|c|c|c|c|c|c|c|c|}
\hline \multirow{3}{*}{ Variables } & \multicolumn{6}{|c|}{ Weaning age } & \multirow{3}{*}{ SEM } & \multirow{3}{*}{ P1 } & \multirow{3}{*}{ P2 } & \multirow{3}{*}{ P3 } \\
\hline & \multicolumn{3}{|c|}{60 days } & \multicolumn{3}{|c|}{90 days } & & & & \\
\hline & $\begin{array}{l}\text { Single } \\
\text { birth }\end{array}$ & $\begin{array}{l}\text { Twin } \\
\text { birth }\end{array}$ & Mean & $\begin{array}{l}\text { Single } \\
\text { birth }\end{array}$ & $\begin{array}{l}\text { Twin } \\
\text { birth }\end{array}$ & Mean & & & & \\
\hline Initial BCS & 2.18 & 2.47 & 2.33 & 2.36 & 1.71 & 2.04 & 0.153 & 0.5745 & 0.1424 & 0.3685 \\
\hline $1-2(\%)$ & 10.0 & 0.00 & 5.56 & 0.00 & 28.57 & 11.76 & & & & \\
\hline $2-3(\%)$ & 50.0 & 25.0 & 38.89 & 60.0 & 28.57 & 47.06 & & & & \\
\hline $3-4(\%)$ & 40.0 & 50.0 & 44.44 & 40.0 & 0.00 & 23.53 & & & & \\
\hline $4-5(\%)$ & 0.00 & 25.0 & 11.11 & 0.00 & 42.86 & 17.65 & & & & \\
\hline Final BCS & 1.86 & 1.53 & 1.70 & 1.68 & 1.29 & 1.49 & 0.109 & 0.2347 & 0.7888 & 0.8409 \\
\hline $1-2(\%)$ & 40.0 & 50.0 & 44.44 & 80.0 & 85.71 & 82.35 & & & & \\
\hline $2-3(\%)$ & 60.0 & 50.0 & 55.56 & 10.0 & 0.00 & 5.88 & & & & \\
\hline $3-4(\%)$ & 0.00 & 0.00 & 0.00 & 10.0 & 14.29 & 11.76 & & & & \\
\hline $4-5(\%)$ & 0.00 & 0.00 & 0.00 & 0.00 & 0.00 & 0.00 & & & & \\
\hline \multicolumn{11}{|c|}{ Egg count per gram of feces (EPG) } \\
\hline Month 1 & 1390.0 & 862.50 & 1126.3 & 635.0 & 100.0 & 368.5 & 294.1 & 0.1874 & 0.3525 & 0.9750 \\
\hline Month 2 & 895.0 & 1387.5 & 1141.0 & 795.0 & 128.6 & 461.8 & 353.5 & 0.3316 & 0.9002 & 0.4066 \\
\hline Month 3 & 55.0 & 100.0 & 177.53 & 190.0 & 185.7 & 187.9 & 33.7 & 0.0930 & 0.7516 & 0.7012 \\
\hline
\end{tabular}

Note: $\mathrm{P} 1=$ weaning age; $\mathrm{P} 2$ = birth type; $\mathrm{P} 3$ = interaction between weaning age and birth type.

60 days had an initial score of 3-4, whereas most of the group that weaned their lambs at 90 days showed an initial BCS of 2-3. At the end of the experiment, most of the ewes that weaned their lambs at 60 days had a BCS of 2-3, whereas the highest percentage of the ewes that weaned their offspring 90 days postpartum showed a BCS of 1-2. Egg count per gram of feces did not differ significantly between the treatments, averaging 747.4 eggs in the first month, 801.4 eggs in the second month, and 182.7 eggs in the third month.

\section{DISCUSSION}

\section{Ewes and Lambs Performance and Return to Estrus}

The average weight change of ewes in the puerperium (weight difference from lambing to weaning) was approximately $-6 \mathrm{~kg}$. This weight loss is a result of the mobilization of energy reserves for milk production during the nursing phase (Campos et al., 2019). In this regard, the most critical period for females are the first eight weeks (60 days) postpartum (Santos \& Godoy, 2017). Particularly during this period, it is of utmost importance that feed be supplied in sufficient quantity 
and quality - as was done in the present study - to minimize weight losses. Weight loss can be influenced by the quality and quantity of available feed, the number of animals fed, environmental factors, and productive potential of the ewe (Campos et al., 2019; Santarosa et al., 2019; Gurgel et al., 2020).

The similar performance of the ewes in the different treatment groups indicates that age at weaning is not an influential factor; i.e., they may accompany their lambs for 60 or 90 days (Table 3). A possible explanation for this finding is that, in these additional 30 days of permanence, those animals have already become ruminants, with a fully developed rumen. Thus, they consume most of their feed in solid-state with improved utilization efficiency and their suckling habit is reduced, allowing the ewes more rest to recover. The observed significant difference $(\mathrm{p}=0.0007)$ in lamb weight-to-ewe weight ratio between the treatments (60 and 90 days), with higher values in the latter group (51.84\%), can be due to the heavier weight of the lambs weaned at 90 days of age since no differences were detected for the ewes (Table 3).

Return to estrus postpartum depends on the nutritional and physiological state of the ewe, lamb suckling time, lactation stage, mother/offspring relationship, and the entire uterine involution process that takes place after lambing (Assis et al., 2011). In the present study, the time for a return to the estrus did not differ significantly ( $\mathrm{p}>0.05)$, averaging 49.5 days postpartum. This can be explained by the fact that feeding type, age, breed, and all ewe management procedures were similar. Considering that the average duration of the anestrus phase postpartum is 27 days, the lambs in the current study were late in resuming estrus postpartum. However, it should be noted that estrus depends on many factors, as previously discussed.

In ewes well-nourished at the end of gestation and at weaning, ovarian activity resumption postpartum compatible with a normal estrous cycle is resumed earlier, which means a shorter lambing interval. As a result, more milk is available to their offspring, whose performance is then increased (Eloy et al., 2011). Our research group found an average period of 35.47 days postpartum for return to estrus in supplemented TexelSanta Ines crossbreed ewes and their lambs on Brachiaria brizantha cv. Marandu pasture in a creep-feeding system (Monteiro et al., 2014), which is a better result compared with the present findings, and 49.37 days for the mothers of un-supplemented lambs.

\section{Body Condition Score and Parasite Control of the Ewes}

Body condition score is directly related to the nutritional status of animals. All ewes received supplementation on top of herbage, which led to satisfactory, but non-ideal body condition (2.5 points). Nevertheless, no differences were observed even when they spent more time nursing their offspring (weaning at 90 days). Ewes with a good BCS at the end of the nursing stage show higher ovulation, conception, lambing rates, and occurrence of estrus (Roberto et al., 2018), which influence the profitability of the system. Roberto et al. (2018) observed that, as the BSC increases, the percentage of pregnant ewes increases, matrices with BSC 3.0, and 4.0 showed $92 \%$ and $98 \%$ of pregnancy, respectively.

Likewise, there were no differences in parasite control (EPG). Parasitic infestation by nematodes compromises animal performance (Melo et al., 2017; Gurgel et al., 2020), as it leads to inefficient use of dietary nutrients, decreased food intake, and reduced absorption and mineral retention (Rosalinski-Moraes et al., 2012; Beasley et al., 2012). In the work of Heimback et al. (2019) the age of weaning (60 or 90 days) did not influence the occurrence of diseases. There was only one case of worms found in the 60-day treatment. However, no animals died, which was probably a consequence of the good animal performance in the two treatments associated with high-quality forage and supplementation. Melo et al. (2017) showed that supplementation of lambs during lactation is an effective strategy, as it increases the productive performance and reduces the parasitic load. The results of performance (Table 3 ) and egg count per gram of feces (Table 4) in the present study, codify with the reports in the literature that prove that adequate nutrition minimizes the adverse effects of the high parasitic load.

\section{CONCLUSION}

The productive and reproductive performance of sheep in Brachiaria spp. pasture can be maximized, regardless of whether they are weaned 60 or 90 days after delivery, as long as they are supplemented. We recommend weaning at 90 days to obtain better lamb performance.

\section{CONFLICT OF INTEREST}

The authors declare that there is no conflict of interest with any financial, personal, or other relationships with other people or organizations related to the material discussed in the manuscript.

\section{ACKNOWLEDGEMENT}

The authors are grateful to the Federal University of Mato Grosso do Sul; National Council of Scientific and Technological Development - CNPq, Foundation to Support the Development of Education, Science and Technology of the Mato Grosso do Sul State FUNDECT; and carried out with the support of the Coordenação de Aperfeiçoamento de Pessoal de Nível Superior - CAPES (Financing Code 001).

\section{REFERENCES}

Assis, R. M., J. R. O. Pérez, J. C. Souza, R. F. Leite, \& J. R. R. Carvalho. 2011. Influence of the suckling management on the estrus return in ewes at post-partum. Cienc. Agrotec. 35: 1009-1016. https://doi.org/10.1590/ S1413-70542011000500020

Beasley, A. M., L. P. Kahn, \& R. G. Windon. 2012. The influence of reproductive physiology and nutrient supply on the periparturient relaxation of immunity to the gastrointestinal nematode Trichostrongylus colubriformis in Merino ewes. Vet. Parasitol. 188: 306-324. https://doi.org/10.1016/j. 
vetpar.2012.03.022

AOAC. 2000. Official Methods of Analysis of AOAC International. $16^{\text {th }}$ ed. Assoc. Off. Anal. Chem., Arlington.

Campos, N. R. F., G. S. Difante, A. H. N. Rangel, S. A. Urbano, J. V. Emerenciano Neto, A. B. G. Costa, R. T. Carvalho Netto, P. H. C. Ribeiro, \& J. I. G. Bezerra. 2019. Supplementation strategies and their effects on ewes colostrum and milk compositions in the initial third lactation period. Semina Ciênc. Agrár. 40:1535-1542. https://doi. org/10.5433/1679-0359.2019v40n4p1535

Chaparro, J. J., N. F. Ramirez, D. Villar, J. A. Fernandez, J. Lodoño, C. Arbeláez, L. López, M. Aristizabal, J. Badel, L. G. Palacio, \& M. Olivera. 2016. Survey of gastrointestinal parasites, liver, flukes and lungworm in feces from dairy cattle in the high tropics of Antioquia, Colombia. Parasite Epidemiol Control. 1:124-130. https://doi.org/10.1016/j. parepi.2016.05.001

Eloy, A. M. X., P. H. F. Souza, \& A. A. Simplicio. 2011. Ovarian activity in Santa Inês sheep under different types of suckling in semi-arid area of Brazil. Rev. Bras. Saud. Prod. Anim. 12: 970-983.

Fernandes, L. S., G. S. Difante, M. G. Costa, J. V. Emerenciano Neto, I. M. M. Araújo, J. L. S. Dantas, \& A. L. C. Gurgel. 2020. Pasture structure and sheep performance supplemented on different tropical grasses in the dry season. Rev Mex Cienc Pecu. 11:89-101. https://doi.org/10.22319/rmcp. v11i1.5083

Gordon, H. Mc. L. \& H. V. Whitlock. 1939. A new technique for counting nematode eggs in sheep faeces. J. Counc. Scient. Ind. Resear. 12:50-52.

Gurgel, A. L. C., G. S. Difante, J. V. Emerenciano Neto, F. F. S. Roberto, L. G. Zaros, M. G. Costa, L. C. V. Ítavo, \& C. C. B. F. Ítavo. 2020. Impact of supplementation with different protein sources on the parasitological profile of ovine matrices and development of lambs. Biosci. J. 36: 496-506. https://doi.org/10.14393/BJ-v36n2a2020-39823

Heimbach, N. S., C. C. B. F. Itavo, L. C. V. Itavo, R. C. Brumatti, G. S. Difante, A. M. Dias, K. L. S. M. Ferelli, T. F. F. S. Arco, A. L. C. Gurgel, C. O. O. Frangiotti, \& P. C. G. Silva. 2019. Weaning age of lambs creep-fed while grazing on marandu pasture. J. Agric. Stud. 7:22-37. https://doi. org/10.5296/jas.v7i4.15354

Leal, T. M., J. F. Nunes, B. Nascimento, H. T. S. Nascimento, \& R. B. Araújo Neto. 2010. Postpartum estrus of Santa Inês Ewe. Rev. Cient. Prod. Anim. 12:158-161. https://doi. org/10.15528/2176-4158/rcpa.v12n2p158-161

Lopes, S.A., M. F. Paulino, E. Detmann, S. C. Valadares Filho, E. E. L, Valente, L. V. Barros, J. E. G. Cardenas, D. M. Almeida, L. S. Martins, \& A. G. Silva. 2014. Supplementation of suckling beef calves with different levels of crude protein on tropical pasture. Trop. Anim. Health Prod. 46: 379-384. https://doi.org/10.1007/s11250-013-0500-6

Lopes, S. A., M. F. Paulino, E. Detmann, E. E. Valente, L. N. Rennó, R. F. D. Valadares, J. E. G. Cardenas, D. M. Almeida, F.H. Moura, \& C. A. S. Oliveira. 2017. Evaluation of supplementation plans for suckling beef calves managed on tropical pasture. Semina Ciênc. Agrár. 38:10271040. https://doi.org/10.5433/1679-0359.2017v38n2p102

Melo, G. K. A., C. C. B. F. Itavo, K. L. S. Monteiro, J. A., Silva, P. C. G., Silva, L. C. V. Itavo, D. G. L. Borges, \& F. A. Borges. 2017. Effect of creep-fed supplement on the susceptibility of pasture-grazed suckling lambs to gastrointestinal helminthes. Vet. Parasitol. 239: 26-30. https://doi.org/10.1016/j. vetpar.2017.04.017

Mertens, D. R. 2002. Gravimetric determination of amylasetreated neutral detergent fiber in feeds with refluxing in beaker or crucibles: collaborative study. J. AOAC Internat. 85:1217-1240.
Monteiro, K. L. S. 2014. Efeito do creep-feeding sobre o par matriz-cordeiro criado em pastagens de Brachiaria spp. Campo Grande. 2014. Dissertação (Mestrado) - Faculdade de Medicina Veterinária e Zootecnia, Universidade Federal de Mato Grosso do Sul, Campo Grande, MS, 2014. p. 58.

NRC (National Research Council). 2007. Nutrient requirements of small ruminants 2th rev. ed. National Academy Press, Washington, DC.

Pompeu, R. C. F. F., M. J. D. Candido, J. N. M. Neiva, M. C. P. Rogerio, M. A. B. Cavalcante, \& R. G. Silva. 2009. Performance of sheep raised on Tanzania grass under intermittent stocking with four proportions of concentrate supplementation. Arq. Bras. Med. Vet. Zootec. 61: 11041111. https://doi.org/10.1590/S0102-09352009000500013

Roberto, F. F. S., G. D. Difante, L. G. Zaros, \& A. L. C. Gurgel. 2018. Nematoides gastrintestinais na ovinocultura de corte sob regime de pastejo. PUBVET. 12:1-12. https://doi. org/10.22256/pubvet.v12n4a65.1-12

Rosalinski-Moraes, F., F. G. Fernandes, A. Munaretto, S. Oliveira, M. O. Wilmsen, M. W. Pereira, \& A. C. F. Meirelles. 2012. Método Famacha@, escore corporal e de diarreia como indicadores de tratamento anti-helmíntico seletivo de ovelhas em reprodução Famacha@. Biosc. J. 28:1015-1023.

Santarosa, B. P., G. N. Dantas, D. O. L. Ferreira, B. Santos, R. K. Takahira, M. G. Carvalho, A. A. Silva, \& R. C. Gonçalves. 2019. Comparação dos parâmetros bioquímicos entre gestação única e gemelar de ovelhas da raça Dorper durante gestação, parto e pós-parto. Arq. Bras. Med. Vet. Zootec. 71:1307-1315. https://doi.org/10.1590/1678-4162-10699

Santos, M. P. S., \& M. M. Godoy. 2017. Desempenho de ovelhas Santa Inês manejadas a pasto e suplementadas com gordura protegida no pós-parto. Rev. Ciênc. Agrovet. 16:136-143. https://doi.org/10.5965/223811711622017136

Sasa, A., K. O. Nonaka, J. C. C. Balieiro, \& L. A. Coelho. 2011. Plasmatic progesterone of ewes submitted to male effect and kept at different nutritional conditions. Arq. Bras. Med. Vet. Zootec. 63:1066-1072. https://doi.org/10.1590/ S0102-09352011000500004

Souza, w. w., E. A. Moraes, J. M. S. Costa, P. H. F. Sousa, E. S. Lopes Junior, R. P. Oliveira, \& R. Toniolli. 2016. Efeito de diferentes concentrações de melatonina em espermatozoides de carneiros sobre estresse oxidativo após criopreservação. Pesq. Vet. Bras. 36: 657-664. https://doi.org/10.1590/ S0100-736X2016000700017

Urbano, S. A., M. A. Ferreira, A. H. N. Rangel, D. M. Lima Júnior, R. P. X. Andrade, \& L. P. Novaes. 2017. Lamb feeding strategies during the pre-weaning period in intensive meat production systems. Trop. Subtrop. Agroec. 20:49-63.

Valente, E. E. L., M. F. Paulino, L. V. Barros, D. M. Almeida, L. S. Martins, \& C. H. A. Cabral. 2014. Nutritional evaluation of young bulls on tropical pasture receiving supplements with different protein:carbohydrate ratios. Asian Australas. J. Anim. Sci. 27:1452-1460. https://doi. org/10.5713/ajas.2014.14085

Valente, E.E.L., M. F. Paulino, E. Detmann, S. C. Valadares Filho, L. V. Barros, N. F. Paula, S. A. Lopes, D. M. Almeida, \& L. S. Martins. 2012. Effect of calves' supplementation on performance, nutritional and behavioral characteristics of their dams. Trop. Anim. Health Prod. 45:487-495. https:// doi.org/10.1007/s11250-012-0245-7

Zvinorovaa, P. I., T. E. Halimani, F. C. Muchadeyi, O. Matika V. Riggioe, K. Dzama. 2016. Prevalence and risk factors of gastrointestinal parasitic infections in goats in low-input low-output farming systems in Zimbabwe. Small Rumin Res. 143:75-83. https://doi.org/10.1016/j. smallrumres.2016.09.005 